\title{
Correspondence
}

\section{Requests for euthanasia in general practice}

SIR

I write re the case conference 'A Request for Euthanasia in General Practice', Journal of Medical Ethics, March, 1983. I am a trainee general practitioner and have frequently found myself faced with patient management situations requiring, strictly speaking, non-medical principles as the basis for decision-making. The case quoted in your journal illustrates this well.

Your commentators rightly point out that it would be wrong to assist a patient to commit suicide and that even the slightest collusion is wrong. However, it is one thing to point out the wrong; it is more difficult to practise the right.

One tells one's patient to take diuretics to keep heart failure under control - this instruction is based at least on the absolute fact that the length of life would be threatened otherwise; on the same principle, one should tell one's patient not to take an overdose of drugs. But if I should say that one should hint to one's patient that it is wrong to commit suicide, I hear the baying of the hounds of consumer interest and patient autonomy; and if I say nothing or collude in any way I may compromise and demean my own awareness of absolute values and their implications.

My fundamental question is this - in situations requiring consideration of principles of ethics, do I bring my own moral standpoint to bear on the issue at stake, or am I simply a servant of the public, acting as a conveyor belt to carry patients along to their own conclusion of the whole matter?

What should the good doctor do? I know that I ask a question that has no categorical answers; and though I do appreciate your commentators' guidance I still feel it is rather timorous.

I make a plea for more discussion and positive guidance especially for junior professionals involved in primary care. CHARLES L CRICHTON, Foresterhill Health Centre, Westbuin Road, Aberdeen.

\section{Right to life of handicapped}

SIR

In reference to your items on the bill drafted by $\mathbf{M r}$ and Mrs Brahams permitting doctors to withhold treatment from newborn handicapped babies, I would like to make the following points.

I am 28 years old, and suffer from a severe physical disability which is irreversible, as defined by the bill. I was born with myelomeningocele spina bifida. Mr and Mrs Brahams suggest several criteria for predicting the potential quality of life of people like me, and I note that I fail to fulfill most of them.

I have suffered considerable and prolonged pain from time to time, and have undergone over 20 operations, thus far, some of them essential to save my life. Even now my health is at best uncertain. I am doubly incontinent and confined to a wheelchair and thus, according to the bill, I should have 'no worthwhile quality of life'.

However, because I was fortunately born in rather more tolerant times, I was given the chance to defy the odds and live, which is now being denied to handicapped newborns. Even so, my parents were encouraged to leave me in the hospital and 'go home and have another' and I owe my life to the fact that they refused to accept the advice of the experts.

Despite my disability I went to an ordinary school and then to university, where I gained an honours degree in sociology. I now work full-time defending the right to life of handicapped people. I have been married eight years to an able-bodied man, and over the years we have travelled widely in Europe, the Soviet Union and the United States. This year we plan to visit the Far East.
Who could say I have 'no worthwhile quality of life'? I am sure though that no doctor could have predicted when I was 28 days old (and incidentally had received no operation at all) that despite my physical problems I would lead such a full and happy life. I do not doubt that they were 'acting in good faith' when they advised my parents to abandon me, but that does not mean that their advice was correct.

I was pleased to see that Dr Havard considered legislation was not the right way to solve the problem, though I suspect his disquiet was rather over an infringement of the liberty of doctors than out of any concern for the rights of the handicapped. Whatever his motives, though, I feel the medical profession could go a lot farther than it has to condemn the constant undermining of the rights of handicapped people at progressively later stages in their lives. There is nothing magical about the age of 28 days after all. It is simply the currently accepted boundary of "nonpersonhood' for babies with congenital defects.

This notion of 'non-personhood' denies the right of handicapped people to be recognised as equal human beings in a caring society, and it makes a mockery of the goodwill which seemingly abounded in the International Year of Disabled People.

Legislation of the type proposed could well also lead to the de facto decriminalisation of the act of killing a handicapped person of any age, just as it did in Hitler's Germany. And if it does, woe betide any handicapped people who are too ill to defend their right to life by protesting that they are in fact happy. And woe betide us all, when we get too old to be considered 'useful' and all the friends who could have spoken in our defence have already been oh so lovingly 'allowed to die'.

MRS ALISON DAVIS, 6 Green Lane, Parsons Heath, Colchester, Essex. 